\title{
AN UNUSUAL ENCOUNTER WITH THE CANADA LYNX
}

WILLIAM J. WALLEY, 222 Bossons Avenue, Dauphin, Manitoba. R7N 0R2

The status of the Canada Lynx (Lynx Iynx) in Riding Mountain National Park in the 1940s was described by $\mathrm{J}$. Dewey Soper as a rare straggler. ${ }^{3}$ Today the species is a common inhabitant of the boreal forests of the park. ${ }^{2}$ Lynx populations are cyclic, fluctuating dramatically with changes in the numbers of its principal prey, the Snowshoe Hare (Lepus americanus). When the hare population is up, tracks of the lynx are regularly identified near our snowshoe trails located kilometres apart among the spruce, fir and tamarack in these forests.

Despite regular sighting of tracks in years of high numbers, the lynx is rarely seen. From the winter of 197071 through 1991-92, I have driven, snowshoed, hiked and canoed approximately $25,000 \mathrm{~km}$ in the park, but I saw only one lynx. By comparison, I saw over 30 wolves ranging from 1 to 13 animals on 6 discrete occasions during this time. Over the same time span, each of four naturalists - outdoor enthusiasts who have similarly spent considerable time in the park or travelling through it - have rarely seen a lynx more than once.

Moon Lake is situated in the boreal forest in the northern sector of the park. The evening of 9 August 1991 was clear and calm as Fern Clyde and I started out on a short hike from the Moon Lake picnic area eastward. At the footbridge over Jackfish Creek near the head of the trail, three men in a canoe reported seeing a lynx near the creek a few minutes before our arrival. Subsequent to crossing the bridge, we were startled to see an adult lynx standing broadside to us on the trail about $12 \mathrm{~m}$ away. With $7 \mathrm{x}$ binoculars the cat was studied for about 20 seconds. Noted particularly were its pene- trating, hypnotic stare, long legs and huge paws, short (in summer) body hair, pointed ear tufts and solid blacktipped tail, the latter being diagnostic in differentiating the lynx from the Bobcat (Lynx rufus). ${ }^{1}$ One leap and it was gone.

Forty minutes later we returned on the same trail. When some $200 \mathrm{~m}$ east of the location of the encounter, childlike wailing was heard which we soon realized came from the lynx. In virtually the same place as first spotted, an adult appeared and padded spiritedly and haughtily toward us displaying confidence and curiosity rather than aggression. Nevertheless, I picked up a dead, club-like branch and instructed my friend to get behind me. When 5 or $6 \mathrm{~m}$ away, the cat turned 180 degrees without breaking stride, seemingly satisfied that we were of no significance to it. As it briskly and light-footedly padded away, a second adult leaped out of the tall grass near the footbridge and started toward us in the same bold, nonaggressive manner. For two or three minutes the lynx activity on the trail blocked our progress, then one at a time the cats crossed the footbridge and seemed to be investigating the vegetation well away from one another. We were then joined by two other people and watched as the cats, one by one, dawdled back across the bridge, sat down on their haunches $2 \mathrm{~m}$ apart and began caterwauling loudly.

For 15 minutes we observed the felines caterwauling at each other at close range. When actually wailing the head was turned almost 90 degrees sideways apparently to avoid eye to eye contact, possibly to avert active aggression. Forty-five minutes later and well after sundown, the caterwauling continued from the same area. The 
cats were not located the next morning when we returned.

In Riding Mountain when, occasionally, large mammals become somewhat habituated to human activity, notably around campsites, and are described as being tame, their presence becomes general knowledge to the park warden and interpretive staff. This would be particularly true of unusual "visitors" such as the Canada Lynx. Inquiries made of the Chief Naturalist in October 1991 and of the Chief Warden of the park in August 1992 provided no information about these lynx at Moon Lake.

What was the significance of the interaction between the two cats and how can their bold behaviour toward humans be explained? Except for brief pairing up during the breeding season in March and early April, adult lynx are usually solitary. ${ }^{4}$ Particular note was taken to determine the sex of these animals. The apparent absence of external reproductive anatomy suggested both cats were female. Lynx are territorial and avoid each other by urination, defecation, and anal scent placed on territorial boundaries. While home ranges overlap, sometimes those of females are fairly distinct. ${ }^{4}$ The most plausible interpretation of the encounter would seem to be a territorial conflict between two females, although no signs of aggression were ever observed.

How can the cats' behaviour toward humans be explained? Evidently, the degree of habituation to humans through earlier encounters was minimal if there was any at all. Did stress generated over the territorial dispute result in displacement behaviour involving the loss of appropriate fear responses to humans? Wrigley has described the tynx as a timid creature, as the rareness of park sightings would indi- cate. ${ }^{4}$. However, some lynx demonstrate a curious acceptance of humans. While on horseback patrol in the Smoky River region of Jasper National Park, Chief Warden Ray Frey came across a lynx on its haunches at the edge of the trail he was travelling (pers. comm.). The lynx looked up at Frey as he rode by. The cat was about a metre or so away from the horse and remained there long after the pack horses behind Frey had passed.

On 15 August 1991, as he was driving through the park, Paul Clark came across a lynx sitting on the top of the ditch back slope along Highway 10 approximately $7 \mathrm{~km}$ north of the Moon Lake encounter site (pers. comm.). He was able to approach it on foot to within $5 \mathrm{~m}$ before it left with its two young when his camera clicked.

This behaviour of the Canada Lynx is in contrast to an experience I had as a youth while exploring the woods with a small group of older boys. We were climbing an aspen-clad ravine in the Birdtail Valley of Birtle, Manitoba, when one of my chums warned that a lynx might attack at any time. Unaware that the area was not lynx country, I expected the cat to spring at us at any moment.

Acknowledgements $I$ thank Chief Warden Ray Frey, Canadian Parks Service, and Paul Clark for their interesting contributions to this note.

1. BANFIELD, A.W.F. 1974. The mammals of Canada. Univ. of Toronto Press, Toronto. p. 393.

2. PARKS CANADA. 1974. List of mammals, Riding Mountain National Park. IAND Pub. No. QS-R006-000-BB-A1.

3. SOPER, J.D. 1961. The mammals of Manitoba. Can. Field-Nat. 75:171219.

4. WRIGLEY, R.E. 1986. Mammals in North America. Hyperion. Press, Winnipeg. $360 \mathrm{pp}$. 